\title{
Developing a Campus Slang Dictionary for the University of Botswana
}

\author{
Thapelo J. Otlogetswe (otlogets@mopipi.ub.bw) \\ and \\ Goabilwe Ramaeba (goabilwe.ramaeba@mopipi.ub.bw), \\ Faculty of Humanities, University of Botswana, Gaborone, Botswana
}

\begin{abstract}
This paper focuses on the study of slang on a university campus for a lexicographic project. The research was conducted at the University of Botswana, a campus comprising circa 16,000 students, most of whom are bilingual in Setswana and English, and a small population of foreign students. Very few studies and documentations of slang have been attempted in an African context (cf. Alimi and Arua 2008; Arua and Alimi 2009), in particular for lexicographic purposes. It is therefore hoped that this study will contribute to filling this paucity of literature. In general, university campuses are rich in slang since they consist of a closed group of persons. Slang is the use of informal words and expressions that are not considered standard in the speaker's language or dialect. It is not just informal but it is also considered a lower register of the standard language, therefore disapproved of by users of standard language. In addition to being common within a specific group, in this case a student group, slang is also general within an ingroup such as a gang or a clique. Because of it being proscribed, slang is usually absent from many African language dictionaries which are largely prescriptive in their documentation of the language (Otlogetswe 2006). In this paper, the design of a dictionary of campus slang is proposed that would capture the wealth of the slang of a linguistic community. The data used for the proposed dictionary was collected on the University of Botswana campus.
\end{abstract}

Keywords: SLANG, SETSWANA, CAMPUS, LEXICOGRAPHY, DICTIONARIES, JARGON

Opsomming: Ontwikkeling van 'n universiteitskampuswoordeboek van sleng aan 'n Afrika-universiteit. Hierdie artikel fokus op die studie van sleng op 'n universiteitskampus vir 'n leksikografiese projek. Die navorsing is gedoen by die Universiteit van Botswana, 'n kampus bestaande uit ongeveer 16,000 studente, die meeste van wie tweetalig in Setswana en Engels is, en 'n klein bevolkingstal vreemde studente. Baie min studies en optekeninge van sleng is in 'n Afrikakonteks onderneem (vgl. Alimi en Arua 2008; Arua en Alimi 2009), veral vir leksikografiese doeleindes. Daar word dus gehoop dat hierdie studie sal bydra tot die aanvul van hierdie gebrek aan literatuur. Oor die algemeen is universiteitskampusse ryk aan sleng omdat hulle uit 'n geslote groep persone bestaan. Sleng is die gebruik van informele woorde en uitdrukkings wat nie as standaard in die spreker se taal of dialek beskou word nie. Dit is nie net informeel nie, maar word ook van 'n laer register as die standaardtaal beskou, en gevolglik afgekeur deur mense wat standaardtaal praat. Benewens dat dit gewoon is in 'n spesifieke groep, in hierdie geval ' $n$ studentegroep, is sleng ook algemeen in 'n binnegroep soos 'n bende of ' $n$ kliek. Omdat dit veroor- 
deel word, is sleng gewoonlik afwesig in baie Afrikataalwoordeboeke wat grootliks voorskriftelik in hul dokumentasie van die taal is (Otlogetswe 2006). In hierdie artikel word die ontwerp van 'n woordeboek van kampussleng voorgestel wat die rykdom van die sleng van 'n taalgemeenskap ondervang. Die gegewens gebruik vir die voorgestelde woordeboek is op die kampus van die Universiteit van Botswana versamel.

Sleutelwoorde: SLENG, SETSWANA, KAMPUS, LEKSIKOGRAFIE, WOORDEBOEKE, JARGON

\section{What is slang?}

Although many have attempted to define slang, it remains a difficult concept. The Oxford English Dictionary (OED, Online Edition) describes slang as a "language of a highly colloquial type, considered as below the level of standard educated speech, and consisting either of new words or of current words employed in some special sense". Webster (Third Edition) defines slang as "a nonstandard vocabulary composed of words and senses characterized primarily by connotations of extreme informality and usu. a currency not limited to a particular region and composed typically of coinages or arbitrarily changed words, clipped or shortened forms, extravagant, forced, or facetious figures of speech, or verbal novelties usu. experiencing quick popularity and relatively rapid decline into disuse". In the preface to the Dictionary of American Slang, Wentworth and Flexner (1960: vi) define slang as "the body of words and expressions frequently used by or intelligible to a rather large portion of the general American public, but not accepted as good, formal usage by the majority". Writers of style manuals especially have generally taken a negative view of slang. Foerster and Steadman (1941: 290) characterise slang as "a cheap substitute for good diction," which demonstrates "laziness in thought and poverty of vocabulary". Fernald (1918: 248) points out that "slang ... saves the trouble ... of thinking. The same cheap word or phrase may be used for any one of a hundred ideas ... Slang is the advertisement of mental poverty."

Slang is therefore a variety of language that is informal and does not conform to convention of vocabulary. Landau (1984: 24) defines slang as "words or expressions that originated in cant (the familiar, non-technical vocabulary restricted to a particular occupation, age, group or any group sharing a special interest). Dumas and Lighter (1978) identify four criteria which are definitive of slang. They argue that an expression should be considered as true slang if it meets at least two of these criteria. These are: (1) Its presence will markedly lower, at least for the moment, the dignity of formal or serious speech or writing ... and an individual who has some familiarity with the expression will not expect to find it in the midst of a serious discourse in otherwise standard English except for one special rhetorical effect: to signal that the speaker or writer is deliberately being undignified or intimate with his audience. (2) Its use implies the user's special familiarity either with the referent or with that less statusful 
or less responsible class of people who have such special familiarity and use the term. This "special familiarity" usually implies disdain for what is conventionally accepted or esteemed, or an overfamiliarity with what the dominant society finds unseemly or unacceptable. (3) It is a tabooed term in ordinary discourse with persons of higher social status or greater responsibility. (4) It is used in place of the well-known conventional synonym, especially in order (a) to protect the user from the discomfort caused by the conventional item or (b) to protect the user from the discomfort or annoyance of further elaboration. Slang is clearly difficult to define though it is not always difficult to identify.

\section{The difference between slang and jargon}

There is need however to distinguish slang from jargon so that in documenting slang, we do not document campus jargon. While a university campus may be rich in slang, it is equally rich in academic jargon which may be mistaken for slang. Southerland and Katamba (1996) define jargon as "a label for vocabulary peculiar to some field; occupational sociolect or language of a particular occupational group". A jargon is therefore terminology which is defined in relation to a specific activity, profession, domain, or event. Therefore the following abbreviations, though obscure to persons outside an academic campus, do not constitute slang, but rather university jargon: C.A. (continuous assessment mark or term mark from tests and assignments), SDF (staff development fellow), FD (fail and discontinue). Other unique terms to a university campus include add and drop which is an action of adding or dropping courses one wants to do in a semester, legal clinic which is a centre for free legal advice that is manned by law students, e-learning which is a system whereby students study or communicate with lecturers and others through technological equipment and freshers' ball which is a music concert organised by students to welcome new students to the university. All these are part of university jargon and not slang and should not be entered in a campus dictionary of slang. Additionally, they do not qualify as slang, because they are neither colloquial nor lower register.

\section{Justification for a dictionary of slang}

Lexicography as a discipline is two-pronged. At one level it is the science and art of dictionary making with a general preoccupation of compiling dictionaries. This is known as practical lexicography. At another level it is what is known as metalexicography, that is, the theoretical and critical arm of lexicography, what Svensén (2009) calls "lexicography about lexicography", that considers the theory and criticism of dictionaries and dictionary theory.

Since lexicography deals with the documentation of all varieties of a language and slang constitutes one of the language varieties, slang is therefore an interesting and important area of study for both practical and theoretical lexicographers. 
The linguistic and lexicographic argument of this paper is therefore that all linguistic variations, whether formal or informal, must be documented and analyzed to better and fully understand the linguistic variations that exist in a speech community. This is in part because language changes and it may be informative to track such changes over time. It may be informative to determine if there are any patterns of how slang terms have been constructed, that is, whether the terms are drawn from technological developments such as microfiche and drive or whether the students reach for their cultural peculiarities such as mopako and mokwele to create slang terminology. Slang documentation is therefore critical since it would document and preserve the different shades of meanings of slang words that exist or have existed and account for how the meanings of certain words have changed over time as well as consider the factors that influenced such changes of meaning.

Slang generally belongs to a closed community and the speakers view it as a part of their identity. Therefore, if a slang word becomes accepted in the "normal" language, the group feels the need to quickly replace it with another unfamiliar one. As a result, slang changes very quickly and that is why it is essential to document the meanings of the words before they are lost.

The documentation of slang will help to show its growth and continuity as a variety of language. It will help to establish if it undergoes the changes that other language varieties go through, such as the coining of new words for new phenomena as a result of technological advancement, new behaviour or attitudes (Aarts and Meijs 1990). English often has new words added to its vocabulary. For example, words such as Facebook and Tweeter with corresponding nouns facebooking, tweets and tweeting and verbs such as facebook and tweet. The documentation of slang will therefore help keep track of issues that influence the creation of the slang terminology of a particular group.

Generally it has been observed that the creation of slang words is not confined to any particular aspect of the users' life but that it covers a range of aspects. According to Dumas and Lighter (1978), Hayakawa (1941) called slang "the poetry of everyday life" and argued that it "vividly expresses people's feelings about life and about the things they encounter in life". This seems to be an accurate reflection of what occurs concerning slang amongst the University of Botswana students. Slang terminology covers their academic, sexual as well as economic life. Alimi and Arua (2008) have identified nine semantic categories under which University of Botswana students' slang can be classified. Some of these include: excellence and poorness, absenteeism, grades, cheating, relationships and the competence and incompetence of their lecturers. This paper's interest is to highlight the importance of documenting and preserving slang as a language variety and to suggest how this could be done.

It therefore considers both practical lexicography and metalexicography. Metalexicography is concerned with conceptual areas of lexicography, dictionary design, dictionary criticism, headword selection, the treatment of idioms, proverbs, verbs, nouns, adjectives, etc. in dictionaries. It is also concerned with 
developing theories regarding the structure and semantic relationships among words in a dictionary.

\section{The user scope of the dictionary}

The proposed dictionary is largely written to document the University of Botswana campus slang. Its main target users are University of Botswana students, in particular new students who are unfamiliar to campus life, and therefore may be uninitiated in campus slang usage. It is hoped that it will help aid the users to quickly become part of the student community, giving them a sense of belonging in a new environment. The publication will also be beneficial to university employees who may be unfamiliar with student slang. The main purpose of the dictionary is to give the meanings of words and where possible, to provide the etymology of some of the entries as well as give examples sentences which demonstrate how the words are used in context. It is hoped that the dictionary will also be of interest to sociolinguistics researchers interested in the language of subcultures within a larger linguistic community. University slang would therefore present such important data for linguistic analysis.

\section{The proposed dictionary type}

The University of Botswana slang consists of several languages, namely Setswana, English and borrowings from other African languages. Because of the bilingualism of the speech community, the dictionary will be unique in that it will comprise words from multiple languages. Inevitably the majority of the words collected are in English, while the rest are mostly in Setswana. The dictionary's entries will therefore be in both English and Setswana, including code-switching and code-mixing, since its target users are largely Setswana speakers who are bilingual in English and Setswana. The definitions of all the entries will be offered in English. The plan is not to make university slang part of a monolingual or a bilingual general dictionary since campus slang is too specialized and not part of the general language.

\section{Data and data analysis}

Most of modern lexicographic data collection and corpus analysis studies use corpora for collecting data, favouring corpora of naturally occurring language. Biber, Conrad and Reppen (1998: 4) have demonstrated that corpus-based analysis is advantageous, because "it is empirical, it analyses actual patterns of use in natural contexts, it makes extensive use of computers" and is capable of providing quantum information from "large and principled collection of natural texts".

Since slang rarely occurs in writing and is usually characteristic of spoken language, a spoken language corpus would be most appropriate for the 
studying of slang on campus. The development of a corpus is however an expensive undertaking and is yet to be developed for the study of University of Botswana slang. Instead, material for this study was collected through a simple questionnaire which asked students to list campus slang terms and their meanings (cf. Arua and Alimi 2009). A total of 1067 respondents were reached through this method. The material was collected, sorted and analysed. It was found that some students confused slang terms with terms which, though colloquial, did not constitute slang. These are colloquialisms such as babe, cool and sharp which cannot be regarded as slang.

Below we present a sample of the collected terms and demonstrate how they could be presented in a dictionary format. In the data presentation the following abbreviations have been utilized: $n$. (a noun part of speech marker), $v$. (a verb part of speech marker) abbr. (marks entries which are abbreviations). Idiomatic expressions carry an [idiom] label. There are also other stylistic usage markers which are bracketed following a part of speech marker. The sample comprises the following usage stylistic markers: (derogatory), (facetious or derogatory) and (facetious, but with strong derogatory connotations). Illustrative sentences are given in italics to exemplify an entry's usage in context. The data that follows is presented as an illustrative sample of the kind of slang data that was collected at the University of Botswana.

ancestor $n$. (derogatory) 1 . an older student who has worked before joining the university for further studies 2. a student who has overstayed their time at the university, especially through retaking and repeating courses. If you don't want to be an ancestor you better finish your program soon = mature.

barracks $n$. old white single storey dormitories on campus that are disliked by students. His room is in the barracks.

caravan $n$. (facetious or derogatory) a large behind or big buttocks. John says his girlfriend's caravan is the one thing that attracted him to her.

caught by a speed trap [idiom] to be caught while copying during an exam or a test. Masego has been caught by a speed trap during our Linguistics test.

crack $n$. an intelligent student who studies hard. Thabang is a crack and his friends who do not study hard take advantage of him. $\operatorname{dog} n$. a young guy; a lad; a chap. $H i$ dog! What's up?

drive $v$. to copy during a test or an examination. Drive here refers to a computer drive, therefore one having access to information in a computer drive. Lebo was caught with a drive in the Chemistry exam.

drop hole $n$. (derogatory) a loose girl who sleeps around. Thato is such a drop hole, almost every boy in my residence block has slept with her.

dubbing $v$. copying from material brought into a test or an examination. Dubbing, one of the older terms used on campus, has its roots in the copying of tapes using tape recorders. Peter has to retake his Physics course because he was caught dubbing during the exam and was disqualified.

exile $v$. 1. to ask a roommate to find alternative accommodation when your boy-or girl-friend is spending the night over in your shared room. To make 
another student leave the room they share and spend the night elsewhere is here compared to one being exiled from their own land. Tshepo exiles his roommate every weekend.

fax $v$. to slip an assignment under a lecturer's door in their absence. This is usually done in the evening in the absence of the lecturer by students who submit their assignments late and want to avoid facing the lecturer. $D r$. Tshane hates it when students fax her their assignments.

fax out of order [idiom] this expression is used when there is no room under the door through which an assignment could be slipped into a lecturer's office. The students were unable to fax their assignments to Dr Tshane because the fax was out of order.

fish market $n$. (facetious, but with strong derogatory connotations) female residences. On Friday nights the fish market is always buzzing with young men hoping for a good catch.

fish pond $n$. (facetious, but with strong derogatory connotations) female residences. On Friday nights the fish ponds are always buzzing with young men hoping for a good catch.

go ja mophato [idiom] to repeat. The word mophato is a noun that refers to an age group, traditionally who join the initiation school together. The expression therefore literally means to drop out of a class of your age group. John $o$ jele mophato too many times and eventually he quit university.

go thuba mmopa [idiom] to talk nonsense or to fail a course completely. The phrase literally means "to break clay". Mpho had to drop his Psychology course because o ne a thuba mmopa.

go tshela class metsi [idiom] to dodge or to miss a class. The expression liter- ally means "to pour water on a class". I had to finish and submit my Sociology assignment, so I had to tshela metsi on my other classes to finish it on time.

gold mine $n$. an older guy showering young women with gifts and money. Lulu's gold mine bought her an expensive phone on Valentine's day.

high risk $n$. a married man or woman in a sexual relationship with a student. Students like high risks because they shower them with expensive gifts and money.

jesa $v$. (derogatory) to lecture poorly. The word means "to feed", so here it is used ironically to show that the lecturer is not really "feeding" the students anything worthwhile. Students do not like junior lecturers, they say ba a jesa.

July conference $n$. a supplementary examination held in July at the end of the academic year. Many students from the Faculty of Science came for the July Conference but many of them still failed their courses.

kgaola $v$. to go: A re kgaole or we'll be too late for class. The word literally means "to cut" in Setswana.

koko ya Setswana $n$. (derogatory) a rural girl or boy who is resistant to modernisation: She is too much of a koko ya Setswana; she will not change her hairstyle and dress sense no matter how hard you try. The phrase means "a free-range local Setswana chicken".

lamza $v$. to kiss: I wish I could lamza that girl, she is very beautiful. The word is not Tswana, but a student creation.

Las Vegas $n$. one of the best looking accommodation blocks on campus considered by students to be modern and of a high standard. Every student on campus wished they stayed in Las Vegas. 
legosha $n$. (derogatory) a female student who uses sex to manipulate men to get money from them. Neo is a legosha, she sleeps with men for money.

leshalala $n$. a girl who maintains high standards of living: That girl ke leshalala, she would do anything to keep up her high standard of living.

le-year year $n$. a third year student and above. It refers to one who has spent many years as a student. They found le-year year intimidating first year students at the bookstore.

madoda score $n$. the $50 \%$ mark in a test or an examination. The Ndebele word madoda means "men" or "gentlemen". John is a hopeless student, he passes all his courses with a madoda score.

majesa $n$. (derogatory) a lecturer who lectures poorly: Our Maths lecturer is such a majesa.

many more $n$. blue movies: They've been watching many more the whole weekend.

matratane $n$. a skinny person. (from the Setswana word 'terata' which means a wire. That girl is such a matratane, you would think she was sickly.

mature $n$. (derogatory) 1 . an older student who has worked before joining the university for further studies. Most mature students work very hard and pass their courses well. 2. a student who has overstayed their time at the university, especially through retaking and repeating courses. If you don't want to be a mature you better finish your program soon $=$ ancestor .

mchine $n$. a corruption of machine; anything of quality; also, an intelligent person. David is a mchine, he passed all his courses with distinction.

microfiche $n$. a page with notes which has been folded multiple times until it is tiny, sneaked into a test or an examination room. Sam was disqualified from writing the exam because he was caught with a microfiche.

mmamochachose $n$. a lady who sells food in the street just outside the university campus. The name comes from a chicken outlet known as Mochachos. Most students prefer to buy lunch from mmamochachose because refectory food is expensive.

mokwele $n$. a male student who is afraid or too shy to approach girls. The word means "a sheep that is given as part of the bride price". Tshepo is a mokwele, he does not have a girlfriend.

mopako $n$. material brought into the test or examination by a student from which they copy: Many students failed the exam, because they were caught with mopaku. The word means "packed food that are taken to school, to work or on a journey".

OA [abbr.] (derogatory) old age, used to refer to older students: $\mathrm{He}$ is an $O A$, but he is only studying for his first degree now.

others $n$. students who are not doing science-based courses or Law. Students who study science courses look down upon others because they think that they are not intelligent.

phoko $n$. a young male who is considered a hero by others because of what he has done or what he does (such as sexual prowess or academic strength). The word in Setswana means "a billy goat". James is a phoko, he has slept with most of the girls in my residence block.

roomza $n$. room mate. Sue and her roomza Pet are best friends.

sack man $n$. a male student without a girl-friend. John is a hopeless sack man who cannot find a girlfriend.

sethubi $n$. a studious student. The word in Setswana means "one who breaks", 
implying that such a student breaks down complex ideas. Lala is a sethubi, she passed all her exams with flying colours.

sexually transmitted degree $n$. degree acquired as a result of having a sexual relationship with a lecturer. Neo had sexual relationships with most of her lecturers, so hers is a sexually transmitted degree and not a genuine one.

sexually transmitted marks $n$. marks acquired as a result of having a sexual relationship with a lecturer. Neo is Prof Dambe's girlfriend, so she passes because of sexually transmitted marks.

single $n$. a room in which one stays alone, allocated only to completing students. Only fourth year students can stay in singles.

squatter boy or girl $n$. an off-campus student who sleeps on campus with another student in their room without the approval of university officials. Many students want to stay off-campus to get the monthly allowance, but then they inconvenience other students by becoming squatter boys and girls in their rooms.

SRB $[a b b r$.] (facetious or derogatory) strong rural background. I like that girl, but she has a high SRB that turns me off. My brother has too much of a $S R B$, he wouldn't marry outside his race.

STD [abbr.] sexually transmitted degree. Neo had sexual relationships with most of her lecturers so hers is a sexually transmitted degree and not a genuine one. swipe $v$. to have casual sex with someone not your boy- or girl-friend. The youth like to swipe a lot, despite the high rate of HIVIAIDS in the country.

thuba $v$. to study very hard. The word literally means "to break". Tshepo wa thuba, although he also parties hard.

tse di fofang $n$. very beautiful girls. The expression means "those that fly", probably in reference to birds. Most of the girls who stay in my block ke tse di fofang.

veteran $n$. (derogatory) one who has overstayed their time at university, because of failing and repeating courses. Mike is such a veteran, he has been at this university for a very long time.

write dry [idiom] to write an examination or a test without having prepared for it. Peter went partying last night instead of studying for his PE test so he wrote it dry this morning.

year year $n$. a student who is doing third, fourth or fifth year: Years years like intimidating new students.

zero-grazing adj. Referring to a student who lives on campus, but does not take their meals from the refectory. This in particular applies to students who are receiving government sponsorship. It is perceived by students as derogatory since a zero-grazing student is one who is stingy and not wishing to spend money on food, preferring to use it for other matters. Zero grazing students are always tired and sleepy because they do not eat well.

The data presented above covers some of the general themes that are typical of a campus environment such as sexual relations between students and lecturers as well as perceptions associated with sexuality on campus. For instance the expression a drop hole refers to a female student of lower morals, to exile another student is to make them spend the night away from their shared room giving space to their roommate to enjoy privacy with a partner. A sack man is a young 
man lacking a girlfriend while a legosha is a female student who exchanges sexual favours for money from men. Sexually transmitted marks and sexually transmitted degrees point to the unethical conduct of students extending sexual favours to lecturers in exchange for favourable grades.

The data also comprises words which expose academic dishonesty by students. For instance mopako is material brought into a test or examination by a student from which they copy while the act of copying is termed dubbing, clearly a term which has its roots in the tape recording period while drive, which also means copying, has its roots in a computer drive. The idiom caught by a speed trap articulates being caught copying in a test or examination.

Other terms articulate the presence or lack of academic brilliance. Go thuba literally meaning to break in Setswana, however in campus slang it means to study hard. An act of studying in this case is perceived as breaking down complex university material into something easy to digest. Jesa, literally meaning feed, is used to characterise a lecturer who delivers his or her material poorly. Such a lecturer in slang terminology is known as majesa - one who feeds. Go ja mophato is an idiom which is used to mean to repeat a year. The idiom is derived from Setswana culture. The literal meaning of the idiom is 'to avoid going to initiation school'. It is therefore evident that going to school is compared to going to initiation school. One who is academically brilliant is termed a crack, a term which is related to go thuba above.

From the data presented, there is evidence that slang demonstrates high levels of creativity. It attaches new meanings to commonly established words that are in general use. For instance, the word mature in general use has positive connotations of one who does things following careful consideration; however, in university slang, it has negative connotations since it means "a student who has overstayed their time at university, especially through retaking and repeating courses". The word fax, a short form for facsimile, is the transmission of scanned text or images to a telephone number connected to a printer or other devices. In university slang, it now negatively means to slide paper material such as an assignment under the door of a lecturer in their absence. Creativity is also visible in the use of fairly well established abbreviations such as STD which in normal usage stands for sexually transmitted disease but in the University of Botswana slang stands for sexually transmitted degrees, something that is perceived as an ill-gotten degree through an exchange of sexual favours with staff for good course marks.

Lexicographically, lexicographers are interested not just in new forms or new words; they are also interested in new meanings associated with established words. Such meanings may be caused by dialectal variation or stylistic differences. Slang creativity is also demonstrated by code-mixing in which a single word contains parts of two or more languages; in our case, Setswana and English. For instance, the word le-year year has a Setswana prefix le- usually associated with nouns of class five of the Setswana noun class system, so that year year then refers to 'many many years'. In other instances, the same meaning 
associated with a common word is then reapplied in a new context. For instance, dubbing means copying tape contents into another tape using a tape recorder. However in slang, it is used to mean copying from illegally brought in material in a test or examination situation. There are also idiomatic expressions such as go thuba mmopa "lit: to break mud" and be caught by a speed trap which are clearly semantically non-compositional and absent in both common expressions of Setswana and English respectively.

From our data analysis, it has become clear that slang terms and expressions used at the University of Botswana are fairly restricted since they are mainly about campus matters such as studying, copying during a test, sexual relationships between students and staff and a few matters relating to campus life. Lexicographically there is a need to deal with dictionary compilation of slang carefully. Decisions must be taken whether the same dictionary will have all the slang headwords though they are from different languages. Will such a dictionary be conceived as a monolingual or bilingual dictionary? Additionally, in the design of a slang dictionary, though slang is informal, lexicographers would have to consider stylistic markers such as offensive or archaic to label terms which fit such labels.

The target users of the proposed dictionary is therefore the University of Botswana students, especially new and foreign students who usually find themselves lost in the web of university slang. Creating a slang dictionary will also document slang usage over the years and provide useful linguistic data of how developments in technology and social life have influenced the development of slang on campus.

\section{Conclusion}

The paper has argued for the importance of the documentation of slang as a language variety of a specific language community. The data has revealed that slang at the University of Botswana exists in both English and Setswana and sometimes the two languages are combined to form a slang expression. Slang like other language varieties is not stagnant; it grows and new terms are frequently added to its lexicon which justifies the need for its documentation. For instance, the expressions microfiche and many more were common in the 1990s and have largely fallen into disuse. The recent expressions from the year 2005 include amongst others zero-grazing, tse di fofang, caught by a speed trap and Las Vegas. Slang is as much a language variety as any other language variety and therefore deserves to be documented and studied descriptively. Since slang generally does not last long, particularly on a campus where students are annually arriving and leaving, there is a need to devise systems and strategies to document it. This paper has argued that the practice of documenting slang is attractive since it will record the shades of meaning over a period of time, changes in word usage and new words that have been created. 


\section{References}

Aarts, J. and W. Meijs (Eds.). 1990. Theory and Practice in Corpus Linguistics. Amsterdam: Rodopi.

Alimi, M.M. and A.E. Arua. 2008. Gender and Student Slang in the University of Botswana. Arua, A.E., M.M. Bagwasi, T. Sebina and B. Seboni (Eds.). 2008. English Language and Literature. Cross-Cultural Currents: 38-53. Cambridge: Cambridge Scholars Publishing.

Arua, A.E. and M.M. Alimi. 2009. The Creation of Students' Academic Slang Expressions in the University of Botswana. Linguistik Online 40(4).

Biber, D., S. Conrad and R. Reppen. 1998. Corpus Linguistics: Investigating Language Structure and Usage. Cambridge: Cambridge University Press.

Dumas, B.K. and J. Lighter. 1978. Is Slang a Word for Linguists? American Speech 53(1): 5-17.

Fernald, J.C. 1918². Expressive English. New York: Funk \& Wagnalls.

Foerster, N. and J.M. Steadman. 1941. Writing and Thinking: A Handbook of Composition and Revision. Revised edition. Boston: Houghton Mifflin.

Hayakawa, S.I. 1941. Language in Action. New York: Harcourt, Brace.

Landau, S.I. 1984. Dictionaries: The Art and Craft of Lexicography. Cambridge/New York: Cambridge University Press.

Otlogetswe, T.J. 2006. Challenges to Issues of Balance and Representativeness in African Lexicography. Lexikos 16: 145-160.

Oxford English Dictionary (OED, Online Edition). http://www.oed.com/view/Entry/181318?rskey= WcfYK5\&result=3\&isAdvanced=false\#eid [Accessed 16 January 2013].

Southerland, R.H. and F. Katamba. 1996. Language in Social Contexts. O'Grady, W., M. Dobrovolsky and F. Katamba. 1996. Contemporary Linguistics: An Introduction: 540-590. London/New York: Longman.

Svensén, B. 2009. Practical Lexicography. Principles and Methods of Dictionary-Making. Oxford/New York: Oxford University Press.

Webster's Third New International Dictionary of the English Language Unabridged. 1961. London: G. Bell and Sons/Springfield, Mass.: G. and C. Merriam.

Wentworth, H.B. and S.B. Flexner. 1960. Dictionary of American Slang. New York: Thomas Y. Crowell. 